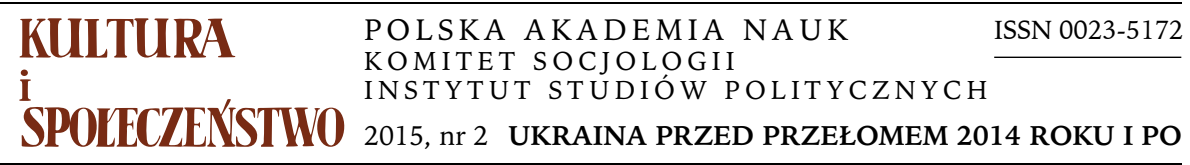

DARIUSZ WOJAKOWSKI

Uniwersytet Rzeszowski

\title{
NARÓD UKRAIŃSKI \\ JAKO PRZEDMIOT POWSZECHNEGO NIEZROZUMIENIA
}

\section{WPROWADZENIE: METODOLOGIA I ŹRÓDŁA}

Badania na Ukrainie nie tylko ujawniają, jak sądzę, problemy związane z kształtowaniem się świadomości narodowej w tamtejszym społeczeństwie, ale także mogą stanowić istotną inspirację do przemyślenia dyskursu akademickiego na temat zjawisk narodowościowych w naszej części Europy. Ogólną ramą mojej analizy są dwie uwagi metodologiczne Clifforda Geertza. Według pierwszej celem badań społecznych jest „poszerzanie uniwersum ludzkiego dyskursu" przez wykorzystanie tego, jak interpretują świat osoby badane (zob. Geertz 2005, s. 30 i nast.). Druga zawiera bardziej konkretne wskazania, jak ów cel zrealizować. Podejście badawcze proponowane przez tego autora to wnioskowanie kliniczne, podczas którego wychodzi się od „zestawu (domniemanych) elementów znaczących i podejmuje próby umiejscowienia ich wewnątrz pewnych zrozumiałych ram. Nie miary dostosowujące się do teoretycznych przewidywań, lecz symptomy (nawet jeśli się je mierzy) są badane pod kątem teoretycznych osobliwości - tzn. diagnozowane" (Geertz 2005 , s. 42) ${ }^{1}$. Celem poszukiwań badawczych z zastosowaniem takiej perspektywy jest dotarcie do sytuacji, przypadków i poglądów formułowanych w przestrzeni społeczeństwa ukraińskiego (i wobec tego społeczeństwa), które rozszerzałyby wiedzę o narodzie, a nie ją potwierdzały. Ważne są więc zja-

Adres do korespondencji: darek.wojak@wp.pl

${ }^{1}$ Szczegółową propozycję wykorzystania tej metodologii Geertza przedstawiam w szerszym opracowaniu (Wojakowski 2007, s. 104-115). 
wiska tworzące przestrzenie „osobliwości”, w których uznane naukowo poglądy dotyczące narodu stają się nieoczywiste. Metodologia takich badań ma charakter jakościowy, co jest szczególnym wyzwaniem w przypadku Ukrainy. Badania ilościowe ukazują bowiem społeczeństwo ukraińskie jako tak bardzo zróżnicowane, że każda pogłębiona diagnoza jakościowa może dotyczyć dość przypadkowego układu wyobrażeń narodowych. Trudno w tym kraju znaleźć odpowiednik Yankee City, które pars pro toto pozwoliłoby zobrazować całość społeczeństwa.

Dyskurs jest ogólną ramą opisową zjawisk kulturowych, przyjęciem pewnej jakościowej perspektywy analizy. W tradycji antropologicznej jest on także traktowany jako konkretna kategoria analityczna (por. Briggs 2001; Clifford 2000). $\mathrm{Z}$ wielości teorii dyskursu istotne są jednak te, dzięki którym można analizować dyskursy o narodzie oraz zestawiać szeroko propagowane akademickie lub polityczne wyobrażenia narodu $z$ ich odpowiednikami potocznymi (lokalnymi) ujawniającymi się w badanych środowiskach (por. Wojakowski 2010, s. 133-138). Wśród nich na szczególną uwagę zasługuje koncepcja Michaiła Bachtina, który wychodzi od „potencjału dyskursywnego” słowa, jego dialogowości (Bachtin 1982, s. 99 i nast.). Słowo istnieje i kształtuje się „W procesie żywej interakcji ze [...] swoistym środowiskiem. Wszelkie konkretne słowo (wypowiedź) znajduje przedmiot [...] zawsze, by tak rzec, już omówiony, przedyskutowany, oceniony..." (Bachtin 1982, s. 102). Dyskursywny charakter każdej wypowiedzi nadają wielorakie konteksty społeczne, przez tego autora nazywane różnojęzycznością. Istotne jest jednak, że owa różnojęzyczność jest zdialogizowana (Bachtin 1982, s. 98). Oznacza to, że wielość kontekstów stanowi układ dynamiczny: „Faktyczne rozwarstwienie i różnojęzyczność stanowią nie tylko statykę, ale i dynamikę życia językowego: rozwarstwianie i różnojęzyczność szerzą się i pogłębiają, dopóki język żyje i rozwija się; obok sił dośrodkowych działają nieustannie odśrodkowe siły języka, równolegle do słowno-ideologicznej centralizacji i integracji rozwijają się procesy decentralizacji i dezintegracji" (Bachtin 1982, s. 97). Należy dodać, że zdaniem Bachtina faktyczne środowisko społeczne jest różnojęzyczne, a owe siły centralizacji i integracji wspierają się na koncepcji jednolitego języka, który „nigdy nie jest czymś danym, zawsze stanowi postulat i w każdym momencie życia językowego znajduje się w opozycji do rzeczywistej różnojęzyczności" (Bachtin 1982, s. 95). W ten sposób Bachtin jako dyskurs traktuje zarówno życie społeczne, jak i tekst, co doskonale pasuje do Geertzowskiej koncepcji zjawisk społecznych, ale jest bliskie socjologii konstruktywistycznej w ogóle (np. Berger, Luckmann 1983). Bachtin zwraca też uwagę na synchroniczną złożoność dyskursu, w której uwidaczniają się przeszłe naznaczenia. Wskazuje na mechanizmy utrzymujące dyskursywny charakter tekstów i języka w ogóle - owe decentralizacyjne siły zjawisk i centralizacyjne tendencje naszych wyobrażeń.

Tak rozumiany dyskurs jest zatem kategorią analityczną, która pozwala zestawiać ze sobą zjawiska $z$ różnych obszarów życia społecznego, z różnych 
jego poziomów ${ }^{2}$. Jednocześnie podkreśla on występowanie napięcia między praktykami społecznymi a tekstem (słowem), ale też wskazuje istnienie napięć $\mathrm{w}$ samych praktykach i słowach. Orientuje to badania na poszukiwanie nowych obszarów niespójności doświadczenia społecznego związanego z narodem ukraińskim $\mathrm{w}$ obecnych $\mathrm{w}$ przestrzeni publicznej tekstach: źródłach internetowych, materiałach publicystycznych i pracach naukowych (te ostatnie jednak traktowane są także jako elementy używane do kreowania dyskursu o ukraińskim narodzie). Oznacza to, że punkty odniesienia dla koncepcji narodu ukraińskiego znajdują się nie tylko w społeczeństwie ukraińskim, ale także poza nim: są to zachodnie i rosyjskie koncepcje narodu i etniczności recypowane przez literaturę ukraińską. Do tej pierwszej kategorii zaliczam etatystyczne, kulturalistyczne, prymordialne, instrumentalistyczne i postmodernistyczne rozumienie narodu (szerzej zob. Wojakowski 2010, s. 139-144). Warto zauważyć, że niezależnie od różnej terminologii i większego lub mniejszego skomplikowania podziału stanowisk teoretycznych koncepcje zachodnie są dobrze rozpoznane w literaturze przedmiotu (Kłoskowska 1996, s. 27-41; Hroch 2003, s. 99-104) oraz w podręcznikach z socjologii narodu (np. Budyta-Budzyńska 2010, s. 23-44). Nie opisuję ich tu zatem, wskazując jedynie, $\mathrm{w}$ jakich kontekstach pojawiają się $\mathrm{w}$ refleksji nad narodem ukraińskim.

Specyficzną kategorią wykorzystanych tu źródeł są elementy doświadczenia badacza terenowego: poza systematyczną obserwacją oraz wywiadami w terenie odbywają się spotkania i rozmowy „po godzinach” i „poza nagraniem”, w „niebadawczych” kontekstach. Trudno jest tym doświadczeniom - samym w sobie - przypisać jakiś walor „eksplikacyjny” czy diagnostyczny. Trzeba jednak przyznać, że w konfrontacji z materiałami z badań i danymi ze źródeł zastanych uwrażliwiają one na osobliwości świata społecznego (por. Kurczewski, Wojakowski 2012, s. 208). Podstawą tej analizy będzie zatem doświadczenie lokalnych badań, które były realizowane we Wschodniej i Zachodniej Ukrainie przed konfliktem ukraińsko-rosyjskim.

\section{POCZĄTEK DIAGNOZY: „POLACY-BANDEROWCY” I SŁABOŚĆ EUROMAJDANU}

W diagnozie różnicowej stosowanej w medycynie, która jest wzorem dla Geertzowskiego wnioskowania klinicznego, zdarza się tak, że dopiero ostatnie wyniki dają zupełnie odmienną i pełną identyfikację zbieranych wcześniej

\footnotetext{
2 Należy zauważyć, że w odróżnieniu od ambitnych założeń nurtu określanego jako krytyczna analiza dyskursu, która stara się ustalić wyraźne zależności (wpływ) między władzą publiczną a konkretną sytuacją społeczną jednostek (por. Faircluogh, Duszak 2008), antropologia społeczna skupia się raczej na wewnętrznych niespójnościach dyskursu/dyskursów (np. Clifford 2000; Crapanzano 1999) lub co najwyżej na współwystępowaniu podobieństw między dyskursami z różnych obszarów życia społecznego (Wojakowski 2010). Podobne „miękkie” ujmowanie dyskursu jako kategorii analitycznej wynika też z przyjętej tu Geerzowskiej tezy o diagnostycznym charakterze badania.
} 
materiałów. Zakończenie badań staje się więc początkiem właściwej diagnozy stanu rzeczy. W podobny sposób ta część, która dotyczy relatywnie aktualnych wydarzeń (relatywnie - w obliczu bardzo szybko zmieniającej się sytuacji w Ukrainie), ma na celu wskazanie pewnych kryteriów interpretacyjnych wyłaniających się ze zjawisk w większym stopniu niż dotychczas ujawniających specyfikę niektórych cech świadomości narodowej obywateli Ukrainy.

Ten kluczowy punkt dla analizy ex post zaczyna się na początku października 2014 roku, paradoksalnie w Polsce i dotyczy Polaków, choć obywateli Ukrainy. W regionalnych i ogólnopolskich mediach głośna stała się sprawa grupy młodych mężczyzn z Ukrainy, którzy sfotografowali się w przemyskiej galerii handlowej z flagą Ukraińskiej Powstańczej Armii (Suchecka 2014). Sześciu z nich okazało się studentami przemyskiej szkoły wyższej. Ponieważ UPA oraz postać Stepana Bandery — lidera OUN (Organizacji Ukraińskich Nacjonalistów), jej politycznej bazy — budzą szczególnie skrajne interpretacje w Polsce i w Ukrainie (por. Wojakowski, Karnaukh 2012), większość polskich komentarzy była bardzo nieprzychylna, potępiały to wydarzenie. Trudno ocenić, jak powszechnie w Polsce obserwowany jest przebieg konfliktu ukraińsko-rosyjskiego, jednak polskie przekazy medialne informowały o tym, że Majdan i nowy rząd ukraiński przez Rosję jest przedstawiany jako nacjonalistyczny, faszystowski i banderowski, co nawiązuje do dawnych i zanikających od początku wieku stereotypów Ukraińca występujących w kulturze polskiej (por. Jestal 1999; Wojakowski 2014). Sprawa obecności symboliki UPA na Majdanie oraz istnienia skrajnych prawicowych organizacji wśród tam protestujących była dostrzegana także w polskich mediach głównego nurtu. Polskie poparcie dla prozachodniego kursu Ukrainy wspólistnieje z obawą przed ukraińskim nacjonalizmem, która nie jest powszechnie wypowiadana, ale wyraźnie wyraża się w poglądach radykalnych środowisk prawicowych. Wydarzenie z przemyskiej galerii handlowej pasuje aż do przesady do promowanego w rosyjskim dyskursie politycznym obrazu znacjonalizowania nastrojów w społeczeństwie ukraińskim. Wszyscy studenci fotografujący się tam z czerwono-czarną flagą okazali się „polskimi banderowcami” - posiadaczami Karty Polaka.

Dużo istotniejsza $z$ perspektywy analizy koncepcji narodu jest jednak reakcja polska: w dyskursie medialnym i na forach internetowych polskość tych osób została mocno zakwestionowana. Co więcej, problem ten jest przedmiotem postępowania przemyskiej prokuratury, która sprawdza, czy osoby te nie wyłudziły (więc nieprawnie nabyły) Karty Polaka (Gorczyca 2014). W narodowym, kulturalistycznym obrazie świata wspólnotę narodową określającym przez podzielanie wyobrażenia o historycznej, kulturowej i politycznej jedności grupy (Anderson 1997) obraz Polaka-banderowca jest bowiem nie do utrzymania. Przyczyną tego jest fakt, że wyobrażony wizerunek wspólnoty narodowej operuje dość schematycznym postrzeganiem przeszłości - jako losów grup i efektów działania podmiotów zbiorowych. Polak-banderowiec staje się ofiarą działań UPA, która jednocześnie musi uzyskać przebaczenie za te działania. 
Tak można odczytać logikę wypowiedzi przemyskiego dziennikarza internetowego:

„Zgrozę budzi także fakt, że studenci ci mają polskie korzenie, tak więc ich przodkowie $z$ dużym prawdopodobieństwem mogli być ofiarami banderowskich czystek. Nie moją rolą jest decydować o ich dalszym losie na uczelni i w Polsce. Jednak czy należy ich bezwzględnie usunąć z naszego Kraju? A może jednak wznieść się na wyżyny wielkoduszności i dać im drugą szansę? Osobiście poparłbym tę drugą opcję, i jeśli nie ma wśród tych młodych ludzi prawdziwych sympatyków UPA pozwoliłbym im na dalsze studiowanie, po zastosowaniu innej kary dyscyplinarnej i jeśli doszło do przestępstwa także karnej. Rozwiązanie to pokazałoby, że tu w Polsce jest miejsce na przebaczenie i chęć dialogu" (Gdula 2014).

Autor ów ma świadomość, że według kategorii przez polskie państwo uznawanych za prawnie określające przynależność narodową, osoby, które wywołały całe to zamieszanie, są jednak Polakami ${ }^{3}$, choć czują się też $\mathrm{w}$ jakimś sensie Ukraińcami. Inne medialne informacje o nich - to, że są mieszkańcami podlwowskiego miasteczka, w którym ukończyli polską szkołę średnią (Szymanik 2014) - pozwalają nawet przypuszczać, że są typowymi Polakami z obwodu lwowskiego. Kategorię typowości odnoszę tu do danych socjologicznych $z$ tego terenu, zbieranych od lat dziewięćdziesiątych XX wieku (Babiński 1997; Wojakowski 2002) do okresu przed konfliktem (Kurczewski 2010): zasiedlenie Polaków w obwodzie lwowskim jest wyspowe, ich aktywność wspiera się na instytucjach Kościoła rzymskokatolickiego oraz polskich towarzystwach kulturalno-oświatowych, które prowadzą działalność edukacyjną (sobotnie szkoły języka polskiego), czasem skupiają się przy utrzymywanych przez ukraińskie państwo szkołach z polskim językiem nauczania (np. Mościska, Lwów).

Badania z końca XX wieku dowodziły raczej istnienia dystansu mniejszości polskiej do państwa ukraińskiego, co przejawiało się na przykład w tym, że badani Polacy w ogóle nie wskazywali na ukraińską tożsamość państwową (por. Wojakowski 2002, s. 237). Te późniejsze pokazują bardziej złożony obraz grupy polskiej, która po Pomarańczowej Rewolucji stała się trwałą częścią lokalnych układów społecznych i politycznych. Relacjonując badania z okresu 2009-2010 wspólnie z Jackiem Kurczewskim podkreślaliśmy ową przemianę w relacjach ukraińsko-polskich. Wskazaliśmy, że w lokalnych interpretacjach tych relacji stosowane jest wyraźne odniesienie do wspólnoty państwowo-narodowej, rozumianej w kategoriach kulturalistycznych i jednocześnie nieco prymordialnych (Kurczewski, Wojakowski 2012, s. 208). Jak sugerowaliśmy: „W tej wersji, [...] Ukrainiec powinien mieć narodowych bohaterów, a Polak, jako obywatel państwa ukraińskiego, lecz również w bardzo esencjalny sposób

\footnotetext{
$3 \mathrm{~W}$ swoim oświadczeniu po incydencie piszą: „Czujemy się związani z narodem polskim jako bracia - wszyscy mamy polskie korzenie" (http://www.pwsw.pl/aktualnosci/id6625,Oswiadczeni e-studentow-PWSW-w-Przemyslu.html).
} 
członek innej nacji, ma prawo do «bohaterów analogicznych»" (Kurczewski, Wojakowski 2012, s. 209).

Doświadczenie badań terenowych wskazywało jednak, że narodowo zorientowane środowiska ukraińskie i polskie bardzo dobrze współpracują, w wyniku czego staraniem mera Drohobycza wybranego przy wsparciu lokalnego środowiska nacjonalistycznego „[...] odnowiono między innymi pomnik poświęcony polskim żołnierzom oraz Siczowym Strzelcom. [...] uroczystości ku czci polskiej i ukraińskiej formacji wojskowej odbywają się wspólnie. Symbole kojarzące się z wrogością między tymi dwoma narodami, a nawet pewne odwołania do walki narodowowyzwoleńczej (wszak przeciw sąsiadom) nie są odczytywane jako źródła wrogości współczesnych mieszkańców miasta. [...] wydaje się, że istnieją w Drohobyczu wzajemnie korzystne powiązania między polską mniejszością a prawicowo zorientowanymi Ukraińcami" (Kurczewski, Wojakowski 2012, s. 209).

Być może owe fakty oznaczały, że już wtedy rysował się schemat, w którym to, co ukraińskie, bardziej łączone było z państwowością niż z kulturą etniczną. Dane $z$ tamtego okresu są niejednoznaczne, lecz trudno zakładać, że świadomość historyczna w Ukrainie jest bardziej pogłębiona niż w krajach Unii Europejskiej, w której coraz większą uwagę zwraca się na nacjonalizm banalny, zorientowany na powszechne, ale proste, słabo uświadamiane przekazy (Billig 2008, s. 90-92). Być może więc obecność flag UPA i postaci Bandery w przestrzeni ukraińskich miast najczęściej (choć oczywiście nie wyłącznie) jest flagowaniem codzienności bez odwołania się do głębszych treści. Przy takim założeniu łatwiej zrozumieć portret Bandery obok portretu Kościuszki w szkole, w której językiem wykładowym jest język polski (badania w 2009 roku), czy dystansowanie się w tym czasie miejscowych Polaków w prywatnych rozmowach od negatywnej oceny działalności Stepana Bandery (w odróżnieniu od bardzo negatywnych ocen formułowanych przez niektóre elity ukraińskie). Oznaczałoby to, że owe symbole - źle kojarzące się w Polsce - na Ukrainie odrywają się od historycznego kontekstu i przechodzą w obszar kultury popularnej, jak William Wallace z twarzą Mela Gibsona w Szkocji (zob. Edensor 2004, s. 202 i nast.). Warto podkreślić, że wzrost popularności symboliki ukraińskiej skrajnej prawicy jest elementem ogólnego nasilenia oflagowania codzienności kolorami państwowymi: niebiesko-żółtymi. To tymi kolorami malowane są tablice informacyjne przy wjeździe do miast wschodniej Ukrainy, dekorowane są pomniki, uczelnie. W tych kolorach pojawiają się przedmioty codziennego użytku (np. długopisy, zeszyty) czy ubiory.

Przywołana koncepcja banalnego nacjonalizmu mieści się $\mathrm{w}$ ramach kulturalistycznych teorii narodu, choć z uwrażliwieniem na to, że fale narodowego uniesienia są raczej emocjonalne niż intelektualne i nieco sytuacyjne. Hipoteza o wzroście banalnego nacjonalizmu w Ukrainie z zamiarem opisania sytuacji społeczeństwa pod presją konfliktu z regionalnym mocarstwem ma jednak słabe umocowanie w teorii. Michael Billig (2008, s. 94) zauważył, że 
w okresach niestabilności politycznej pojawia się raczej gorący nacjonalizm. Odmienna interpretacja tych faktów, a przede wszystkim tego, że ukraińscy Polacy „podtrzymują swoje państwo” za pomocą flagi UPA, może być taka, że w warunkach zewnętrznego konfliktu wymuszany jest konformizm grupowy, a konsensus narodowy przesuwa się wyraźnie w kierunku nacjonalistycznej prawicy (która nota bene odegrała istotną rolę w odsunięciu Wiktora Janukowycza od władzy) ${ }^{4}$. W październiku 2014 roku ta hipoteza była bardzo kusząca, ponieważ można było się spodziewać, że planowane na 26 października wybory parlamentarne dadzą szybką i rzetelną jej weryfikację.

Zauważyć należy, że w wyborach z 2012 roku znaczącą pozycję zdobyła nacjonalistyczna partia Swoboda, która w skali kraju miała ponad dziesięcioprocentowe poparcie, w byłej Galicji uzyskała ponad 30\%, a w obwodzie lwowskim zwyciężyła, zdobywając $38 \%$ głosów ${ }^{5}$. Ten sukces oraz wcześniejsze (w roku 2010) ogłoszenie Stepana Bandery bohaterem narodowym Ukrainy sugerowały powszechniejsze pojawianie się etatystycznego i jednocześnie prymordialnego ujmowania idei narodowej, zgodnie z Gellnerowską zasadą, że państwo jest dla tylko jednej grupy kulturowej (Gellner 1991). Podczas nieco wcześniejszego badania ilościowego w Drohobyczu zapytaliśmy o możliwość pojednania ukraińsko-polskiego, wprowadzając odpowiedź, która miała pasować do takich, jednoznacznie nacjonalistycznych przekonań, czyli stwierdzenie: „O wszystkim, co było, trzeba mówić głośno, tak aby nie ukrywać prawdy, gdyż prawda jest ważniejsza od pozornego porozumienia". 11,7\% respondentów zgodziło się $z$ tą tezą (por. Kurczewski, Wojakowski 2012, s. 201), co wskazuje pewien lokalny fundament wyraźnie nacjonalistycznych poglądów występujących w mieście, w którym partie narodowe zawsze miały znaczące poparcie.

Wybory z jesieni 2014 roku — prowadzone w warunkach konfliktu $z$ sąsiednim państwem - nie zmieniły zasadniczo rozkładu popularności radykalnego nacjonalizmu. Co prawda, Swoboda uzyskała gorszy wynik $(4,71 \%)$, ale gdy dodamy do tego wynik Partii Radykalnej oraz Prawego Sektora - otrzymamy łącznie $14 \%$. Prawdopodobnie w obwodzie lwowskim było podobnie - próg $5 \%$ nieznacznie przekroczyły Swoboda i Partia Radykalna ${ }^{6}$. Wyniki z obwodu lwowskiego (kilkanaście procent poparcia wobec wcześniejszych $38 \%$ dla Swobody) pokazują tak znaczące przepływy elektoratu, że trudno jest dopasować do nich jakieś teoretyczne wyjaśnienie. Olha Suprunenko analizując społeczeństwo ukraińskie zwracała uwagę, że niestabilność działań jednostek w tym społeczeństwie może wynikać z niejasności czy niepewności społecznych sensów:

\footnotetext{
4 W dosadny sposób teza ta została zaproponowana w Przemyślu: „Na Ukrainie banderyzm szerzy się dziś jak nigdy" (Gdula 2014).

5 Dane za Centralną Komisją Wyborczą Ukrainy (http://www.cvk.gov.ua/pls/vnd2012/ wp315?PT001F01 =900).

${ }^{6}$ Informację podaję w przybliżeniu, dlatego że Centralna Wyborcza Komisja Ukrainy nie podaje w regionach wyników partii, które nie uzyskały poparcia większego niż 5\% (http://www.cvk.gov. ua/pls/vnd2014/wp315? PT001F01 =910).
} 
„dzisiejszy Ukrainiec znalazł się na przecięciu kilku procesów o decydującym znaczeniu i niezliczonej ilości drobnych procesów, powodujących osuwanie się realiów, do których był przywiązany" (Suprunenko 2008, s. 136). W tej sytuacji, uważa autorka, jednostki najczęściej stosują pewne interpretacje rzeczywistości o charakterze adaptacyjnym, polimorficznym i tymczasowym. „Wobec tego - pisze Suprunenko (2008, s. 137) — po dzisiejszym mieszkańcu Ukrainy nie należy się spodziewać zdecydowanych działań w sferze życia codziennego popartych szeroką orientacją i harmonijnym stanem wewnętrznym". Oznaczałoby to, że nawet zjawisko „oflagowania codzienności”, wynikające z mechanizmów emocjonalnych opartych na prostych symbolach identyfikacji z państwem czy narodem, jest sytuacją doraźną i nie przesądza o trwałości symboliki czy identyfikacji.

W tym kontekście pojawia się drugi — obok upowszechnienia się symboli narodowych - znaczący problem: pojawienie się cech społeczeństwa obywatelskiego. Zarówno Pomarańczowa Rewolucja 2004 roku, jak i Euromajdan to zjawiska, które są odczytywane jako ruchy społeczne o charakterze obywatelskim. Serhij Yekelchyk (2009, s. 280) ocenił politykę niepodległej Ukrainy jako budowanie obywatelskiej koncepcji społeczeństwa: „Z dwóch modeli narodowości - etnicznego, który miałby obejmować wyłącznie etnicznych Ukraińców, i obywatelskiego, w którym mieszczą się wszyscy obywatele nowego ukraińskiego państwa - budowniczowie narodu zdecydowanie wybrali ten drugi". Ramy prawne i polityczne państwa ukraińskiego potwierdzają tę ocenę (zob. Karnaukh 2015, s. 87-101) i być może siła protestów wspierała się też na owym nominalnym uznaniu podmiotowości narodu obywatelskiego. Jednak przywołane wydarzenia polityczne cechowały się raczej gwałtownością i krótkotrwałością rewolucji niż procesualnym tworzeniem obywatelskiej siły społeczno-politycznej. Należy też dostrzec, że protesty - mimo że miały charakter masowy i pojawiały się nie tylko w Kijowie - nie obejmowały większości mieszkańców Ukrainy. Bardzo istotnym wskaźnikiem tej segmentowości (a tak naprawdę wyspowości) ruchów obywatelskich jest frekwencja w wyborach parlamentarnych 2014 roku, w których wzięło udział nieco ponad połowę uprawnionych $(52,42 \%)$. Wynik ten nie daje pewności, że zmiana „symbolicznego krajobrazu” ukraińskich miast realnie wpłynęła na „obraz ukraińskiej duszy".

Ukraiński dyskurs polityczny po Majdanie wciąż zachowuje dualistyczny charakter. Z jednej strony daje się zauważyć wsparcie dla idei narodowej i państwowej, z drugiej - demokratyczna legitymizacja tych idei jest wyraźnie słabsza niż na przykład poparcie dla zmian politycznych w Polsce w 1980 i 1989 roku. To zestawienie jest istotne, gdyż trudno uznać społeczeństwo polskie za typowy przykład społeczeństwa obywatelskiego — raczej wskazuje się na jego niedorozwój w porównaniu z społeczeństwami zachodnimi. W społeczeństwie ukraińskim legitymizacja jest zatem słabsza niż w nie najlepiej pod tym względem w ramach Unii ocenianej Polsce. 
Mocne akcenty narodowe i obywatelskie oraz proeuropejski sprzeciw wobec nieuczciwej władzy nie dowodzą zatem siły dyskursu narodowego w ukraińskim społeczeństwie. Sytuacyjne poparcie dla narodowej symboliki nie jest twardym wskaźnikiem istnienia idei jednego narodu kulturowego, niska frekwencja wyborcza zaś nie pozwala nawet na stwierdzenie, że symbolika ta wyraża silne poparcie dla idei jednego państwa. Chyba że państwo to postrzegane jest przez jego obywateli w innych kategoriach, niż przyjmuje się w dyskursach zachodnioeuropejskich.

\section{TEORIE NARODU I SOCJOLOGICZNE PODRĘCZNIKI}

Przywoływana już Olha Suprunenko (2008, s. 138) na zakończenie swej analizy stwierdza, że „Ukraina zmierza drogą potocznej i naukowej stabilizacji swojego obrazu świata". Oznaczałoby to, że w dyskursie akademickim oraz w codziennym (banalnym) uzusie interpretacyjnym pojawiają się nie tylko Bachtinowskie siły różnicujące (różnojęzyczność), ale też centralizujące i integrujące. Żadna z tych sił nie musi i nie może uzyskać wyłączności w dyskursach o narodzie. Istnienie sił centralizujących pozwala jednak na zbudowanie przekonania o możliwości wzajemnego zrozumienia niezależnie od faktycznej społecznej różnojęzyczności. Ta część analizy poświęcona jest dyskursowi naukowemu w Ukrainie, który właściwie powinien być jednym $z$ istotnych czynników integrujących całość dyskursów społecznych dotyczących narodu ukraińskiego ${ }^{7}$.

Ukraińskie socjologiczne teorie narodu zostały przeanalizowane przez Allę Karnaukh (2015). Zwraca ona uwagę na dwa istotne, moim zdaniem, elementy socjologii ukraińskiej: silną zależność współczesnych badań ukraińskich od zachodnich koncepcji narodu oraz problem rozróżnienia terminów „nacja” i „naród”. To pierwsze zjawisko opisane jest raczej przez wyliczenie badaczy wprost odwołujących się do autorów zachodnich, gdyż autorka skupia się bardziej na cechach specyficznych prac ukraińskich. Podsumowując dyskurs akademicki przywołuje tezę Heorhija Kasjanowa: „Teoretyczne i empiryczne badania «ukraińskiej wersji» stanowienia i rozwoju narodu i nacjonalizmu odpowiadają wnioskom i uogólnieniom, które zostały sformułowane $\mathrm{w}$ oparciu o doświadczenia konkretnych szkół europejskich. To podobieństwo może być wytłumaczone jako "drugorzędność» (opóźnienie) ukraińskiego nacjonalizmu wobec narodów europejskich, narodów wcześniejszych" (Kasjanow 1999; cyt. za: Karnaukh 2015, s. 34-35).

Zdaniem Karnaukh (2015, s. 35), rozważania ukraińskich badaczy pozostają $\mathrm{w}$ granicach teorii zachodnich. Wydaje się, że faktycznie nie tylko badacze

${ }^{7}$ Argumentem za taką tezą jest choćby sugestia Giddensa (2001, s. 4), że nauki społeczne stanowią zinstytucjonalizowaną refleksyjność, dostarczają więc uczestnikom życia społecznego odpowiednich narzędzi do jego zrozumienia. 
wspomniani w jej analizie (Bałuk, Hołowacha, Kasjanow i in.) orientują się na dopasowanie dzisiejszych ukraińskich doświadczeń do zachodnioeuropejskich kategorii. W innych pracach traktujących o teorii narodu punktem odniesienia również jest literatura zachodnia (np. Kuzio 2002; Panina 2004). Także badacze świadomości ukraińskiej, podejmujący się przedstawienia jej historycznych przemian, do opisu procesów narodowościowych przywołują te same schematy, traktując je jako typowe dla tej części Europy (por. Yekelchyk 2009; Hrycak 2000). Jarosław Hrycak (2000, s. 64-66), odwołując się explicite do koncepcji Benedicta Andersona, wskazuje przyjęcie takiej perspektywy jako sposób na uniknięcie błędów ukraińskiej i radzieckiej historiografii w opisie tworzenia się narodu ukraińskiego (zob. Hrycak 2000, s. 12-16).

Jeśli jednak stosujemy taką perspektywę podczas analizy narodu ukraińskiego, to pojawia się problem dualizmu procesów narodowych. „Solidarność narodowa ukraińskich mas w Galicji - pisze Yekelchyk (2009, s. 92) - pozostawała jednak w wyraźnym kontraście wobec ambiwalentnych samokreśleń narodowych i społecznych w części Ukrainy rządzonej przez Rosjan". Wskazuje, że ta słabość z początku XX wieku widoczna była też pod koniec stulecia, kiedy główną przyczyną stworzenia niepodległego państwa był rozpad ZSRR oraz porozumienie elit: opozycyjnych i komunistycznych (Yekelchyk 2009, s. 277-278). Zdaniem Jarosława Hrycaka (2000, s. 337), wspó1cześnie w ukraińskim dyskursie ścierają się dwie idee „narodowe”: ukraińska i radziecka, a ich popularność rozkłada się geograficznie wedle podziału zachód-wschód. Podział ten nakłada się na odmienności uchwytne w danych ilościowych. Są to odmienności religijne (por. Pawluczuk 1998, s. 52 i 122-125), językowe (Riabczuk 2004, s. 78-86; Karnaukh 2008, 2009) i tożsamościowe (Czernysz 2002; Hrycak 2002), które doskonale pasują do Huntingtonowskiego modelu zderzenia cywilizacji zachodniej i rosyjskiej na linii przedwojennej granicy Polski i ZSRR (zob. Huntington 1997, s. 263-268). Niektórzy z tych badaczy (Riabczuk i Pawluczuk) traktują ów dualizm jako zasadniczą cechę społeczeństwa ukraińskiego. Inni podkreślają złożony, lecz niekoniecznie dualistyczny czy dychotomiczny obraz Ukrainy. Jest on niejednoznaczny, gdyż wspólnym dziedzictwem obszaru postradzieckiego jest to, że nie wytwarzają się tu „wyraźnie, wzajemnie się wykluczające tożsamości grupowe” (Hrycak 2002, s. 27). Natalia Czernysz (2002, s. 13) sugeruje, że równie istotnym jak podział terytorialny czynnikiem różnicującym narodowe i obywatelskie identyfikacje jest wiek badanych, a spektrum wyboru tożsamości społecznej jest dużo szersze niż wybór między Ukraińcem/Rosjaninem/człowiekiem radzieckim (Czernysz 2002, s. 9). Zdaniem Hrycaka (2002, s. 29), badania socjologiczne wskazują raczej, że „[...] formowanie się tożsamości ukraińskiej jest, co prawda, problemem w Ukrainie - ale problemem zupełnie nie najważniejszym. Wprost przeciwnie, można stwierdzić, że ze wszystkich problemów, które przeżywała Ukraina w ostatnich dziesięciu-piętnastu latach, utrzymywanie narodowej stabilności wbrew wielkim regionalnym i językowo-kultu- 
rowym podziałom jawi się jako problem, który najlepiej poddaje się regulacji".

Wniosek z tego jest jednak taki, że dualizm dyskursu politycznego ma także swój odpowiednik w dyskursie tożsamościowym, gdyż pojawiają się badania i interpretacje, które akcentują bądź to względną jedność tożsamościowych procesów w Ukrainie, bądź nieusuwalną różnicę tożsamości ukraińskich. Może mieć to związek $z$ ogólną teorią narodu w Ukrainie, która niezależnie od popularności stanowisk zachodnich zachowuje dwoistość kategorii opisujących grupę narodową: narodu i nacji.

Według koncepcji Michaiła Bachtina narzędziem sił centralizujących jest język. Stosowanie pewnych kategorii w języku — akademickim i potocznym może zbliżać dyskursy ukraińskie albo do zachodniego sposobu myślenia, albo do rosyjskiego. Podane wcześniej przykłady pokazują te elementy dyskursu, które orientują się na centralizację na bazie kategorii zachodnich. Pojęcia narodu i nacji wiążą myśl ukraińską z tradycją rosyjską. Ten związek zauważa Alla Karnaukh, lecz wcześniej podjął go Włodzimierz Pawluczuk (1998, s. 17-18) w rozważaniach na temat idei euroazjatyzmu Lwa Gumilowa. Jak zauważa Karnaukh (2015, s. 33), autorzy ukraińscy dobrze znają teorię Gumilowa, jednak niezbyt chętnie ją stosują. Może być to związane ze współczesnym jej wykorzystaniem w socjologii rosyjskiej. Roman Kiś (2005, s. 18-20) sugeruje, że prace Dugina, Plieszkowa i in. to podstawa „rewanżystowsko-imperialnej polityki Kremla”, która jest „fundamentalnie antyzachodnia”, jednocześnie twierdząc, że euroazjatyzm „wypełnia myśli, serca, codzienne relacje i samo życie dziesiątek milionów w miastach i wsiach Ukrainy". Jest to zarazem wytłumaczenie niechęci badaczy ukraińskich do tej teorii i uznanie tez Pawluczuka, że wschodnie schematy postrzegania problematyki narodowej nie są obce potocznemu doświadczaniu narodu ukraińskiego.

Współczesną rosyjską wersję kategorii Gumilowa proponuje Aleksandr Dugin $(2004 ; 2011)$. Oczywiście, podstawą jest etnos jako „organiczna, żywa całość" (Dugin 2011, s. 11), co przekłada się na sugestię, że etnos ma związek z moralnością oraz sferą ducha (Dugin 2011, s. 8-9). Dla celów tej analizy kluczowe jest jednak ulokowanie w teorii Dugina kategorii narodu i nacji. Jego zdaniem: „naród to etnos, który wstąpił w historię” (Dugin 2011, s. 33). Naród taki jest produktem złożonym $z$ różnych warstw społecznych (elity i masy), powstałych $\mathrm{w}$ wyniku zdominowania przez jeden etnos innych etnosów. Jednocześnie naród obejmuje sobą etnos, ma jednak odrębne właściwości, w etnosie się nie ujawniające. Następnie Dugin (2011, s. 34) stwierdza, że: „naród jako fenomen historyczny przybiera oczywiście odpowiednie formy: państwo, religia, cywilizacja. Formy te mogą występować niezależnie [...], albo też razem lub w dowolnej konfiguracji. [...] naród zapewnia tym formom trwałość, ciągłość i realność".

Naród jest zatem bytem zachowującym istotne właściwości prymordialne, $\mathrm{w}$ jakie wyposażony był etnos. Ponadto jest on aktywnym podmiotem historii, 
nadaje sens formom, w których się przejawia. Poglądy takie można dostrzec bardzo wyraźnie w innej pracy Dugina (2004) poświęconej euroazjatyzmowi. Autor odnosi się w niej do konkretnej sytuacji etnosu i narodu „ruskiego” i podejmuje teoretyczną próbę uzasadnienia politycznych roszczeń współczesnej Rosji do odnowienia wpływów na obszarze byłego ZSRR. Jest to ów imperialistyczny rys poglądów Dugina, który wskazuje cytowany już Kiś.

Termin „nacja” odnosi się do zjawisk, które nie mają już takiego autotelicznego znaczenia. „Nacja - pisze Dugin (2011, s. 36) - to pojęcie bardzo polityczne, nierozerwalnie związane $z$ państwem, nawet $z$ państwem konkretnym — dzisiejszym europejskim, burżuazyjnym państwem modernistycznym". Jest to, co prawda, jedna $z$ fundamentalnych kategorii teorii Dugina, będąca pochodną etnosu, opierająca się na narodzie, choć jakościowo od niego odmienna z racji złożoności i zróżnicowania. Tak jak naród ukrywa w sobie etnos, tak nacja ukrywa za „swoją fasadą” naród.

Ciekawe jest to, że taka założona obiektywna „struktura” etnicznych kategorii służy Duginowi do wyjaśnienia sporów między prymordializmem a konstruktywizmem w socjologii zachodniej. Etnos jako byt duchowy i naród jako byt historyczny powinny być opisywane w kategoriach prymordialnych (choć uznaje on, że pewne elementy narodu są konstruowane). Nacja jako produkt zachodni daje się opisać tylko w kategoriach konstruktywistycznych (Dugin 2011, s. 64-65), które — podobnie jak instrumentalizm — zasadniczo są mało adekwatne do opisu kategorii etnicznych, przydając się jedynie do analizy specyficznych zjawisk w społeczeństwach zachodnich (Dugin 2011, s. 71) ${ }^{8}$.

Czy ukraińskie wyobrażenia nacji i narodu są podobne? Już na poziomie prostej refleksji nad sytuacją w dzisiejszej Ukrainie można podać w wątpliwość tezę, że idea euroazjatycka jest w pełni uznawana przez „dziesiątki milionów” mieszkańców Ukrainy. W takiej sytuacji dzisiejszy obraz konfliktu rosyjsko-ukraińskiego wyglądałby nieco inaczej i zdecydowanie na niekorzyść Ukrainy. Być może proste przyłożenie schematów rosyjskich jest takim samym źródłem niezrozumienia problemów narodowych w Ukrainie, jak wprowadzanie modeli zachodnich.

W ukraińskim dyskursie akademickim użycie pojęć narodu i nacji jest odmienne niż u Dugina. Właściwie wszyscy przywołani już autorzy uważają, że są to terminy prawie równoznaczne. Alla Karnaukh (2015, s. 31-32) analizując poglądy kilku znaczących ukraińskich autorów zauważa: „W języku ukraińskim w sytuacjach oficjalnych oraz mniej oficjalnych, w języku potocznym, panuje

\footnotetext{
${ }^{8}$ Nie można nie zauważyć, że dokonany przez Dugina krytyczny przegląd zachodnich teorii socjologicznych nie otwiera nowej perspektywy poznawczej, lecz jest próbą obrony stanowiska nauki dziewiętnastowiecznej. Przywołane tu koncepcje są kalkami poglądów Ludwika Gumplowicza, a przede wszystkim dziewiętnastowiecznych poglądów historyków konserwatywnych, dla których naród jest całością społeczną, „która z zasady nie poddaje się racjonalizacji, odsyłając nas jedynie do intuicyjnie uchwytnej "zasady organicznej», jaką jest charakter narodowy" (Szacki 2002, s. 172). $\mathrm{Na}$ te powiązania zwróciła mi uwagę Agata Nijander-Dudzińska.
} 
pewien chaos definicyjny: dla określenia Ukraińców jako grupy etnicznej często używa się pojęcia nacja, natomiast, by podkreślić wszystkich obywateli naród ukraiński”. Przywołuje też Konstytucję Ukrainy, w której „nacja ukraińska” i „naród ukraiński” pojawiają się po sobie w preambule (Kanaukh 2015, s. 32). Sama zaś uznaje rozwiązanie tego problemu przyjęte przez Włodzimierza Pawluczuka. Autor ów stwierdza, że naród i „nacja oznacza mniej więcej to samo, używa się jednak tego pojęcia, gdy chce się wydobyć aktywny aspekt narodu walczącego o swoją państwowość" (Pawluczuk 1998, s. 68). Dość długie rozważania Serhija Yekelchyka (2009, s. 7-10) na temat nacji mają na celu nie tylko ukazanie odmienności znaczeniowej tego terminu (choć taką interpretację uznaje ów autor), ale ulokowanie go w kontekście etatystycznego i kulturalistycznego rozumienia narodu. Kojarząc nację z koncepcją kulturalistyczną wyraźnie umieszcza tę kategorię w ramach dyskursu zachodniego (zob. Wojakowski 2010, s. 140-141).

Ważnym elementem dyskursu akademickiego są podręczniki - jako pośrednik między akademickim myśleniem o narodzie (słowie) a praktycznymi wyobrażeniami społecznymi (praktyki). Jest tu niemożliwe całościowe przedstawienie tej kategorii tekstów, ale na przykładzie dwóch podręczników z Równego i Kijowa, aprobowanych przez ukraińskie Ministerstwo Oświaty i Nauki, można podjąć próbę oglądu interesujących nas kategorii w świetle dotychczasowych ustaleń. W „Podstawach socjologii” Jewheniji Tychomyrowej (Równe) nie pojawia się pojęcie narodu, lecz wyłącznie etnosu i nacji. Choć przedstawia ona koncepcję Gumilowa, wskazuje też, że inni autorzy uważają, „iż zarówno etnos, jak i nacja to wyłącznie społeczne zjawiska" (Tychomyrowa 2007, s. 139). Opis nacji jest klasycznym przedstawieniem zachodnich teorii narodu (bez odwołania się do dyskusji z ostatnich dwóch dekad, które nota bene uwzględnia Dugin). Szerzej natomiast jest opisana tradycja ukraińskiego rozumienia nacji, która jednak bazuje na typowych cechach zachodniego postrzegania narodu: świadomości politycznej, specyfice kulturowej i posiadaniu państwa (Tychomyrowa 2007 s. 144-145).

Drugi podręcznik, redagowany przez Wołodymyra Piczę, ma charakter słownikowy i pojawiają się w nim wszystkie trzy terminy. Etnos jest tam definiowany jako „szczególny typ wspólnoty ludzi, która powstała historycznie i jest specyficzną formą ich kolektywnego bytu" (Picza 2002, s. 115). Podstawą tej wspólnoty jest język, religia i samoświadomość, a formami narodowość i nacja (Picza 2002, s. 116). Opis tej kategorii łączy pewne elementy rozumienia etnosu oraz etniczności, pojmowanej bądź jako tożsamość, bądź jako cechy kulturowe grupy (por. Babiński 1997, s. 28-31). Naród ma dwa rozumienia. Szerokie to „Wszyscy mieszkańcy danego kraju lub państwa. W wąskim sensie o narodzie można mówić jako o odrębnym etnosie" (Picza 2002, s. 237). Co prawda, w szczegółowym opisie pojawiają się treści znane z pracy Aleksandra Dugina - jak to, że naród składa się z różnych warstw społecznych — ale pojęcie to wygląda dość sztucznie (nie jest też przywołane w opisie etnosu). Jego 
szerokie rozumienie przypomina Duginowskie „społeczeństwo obywatelskie” (zob. Dugin 2011, s. 39-40) i być może jest taką zbitką dwóch idei: zachodniej, społeczeństwa jako wspólnoty obywateli, i wschodniej, w którym społeczeństwo jest podmiotem historyczno-moralnym. Nacja jest terminem opisującym „nowoczesne narody”, które są przedmiotem „socjologii nacji” (Picza 2002, s. 240-241), ogólnie zatem pasuje do zachodniego rozumienia narodu. Jako źródłosłów tego terminu podane jest natio (z tłumaczeniem народ, плем’я), raz też termin „naród” traktowany jest w tym tekście jako zamiennik nacji.

Wpływ rosyjskich koncepcji narodu i nacji na literaturę ukraińską wydaje się słabszy niż teorii zachodnioeuropejskich. Jednak wszystkie wymienności i współobecności narodu i nacji w tekstach akademickich nie budują przekonania o „naukowej stabilizacji obrazu świata” z tezy Olhy Suprunenko. Widoczne różnice nie są przy tym dramatycznym rozdarciem, ale zapewne sytuacyjnym dopasowywaniem posiadanych narzędzi kategorialnych. Powoduje to jednak, że trudno jest rozpoznać, w którym momencie odwołując się do ukraińskości mamy na myśli naród kulturowy, naród polityczny czy społeczeństwo obywatelskie. Takie akademickie rozważania nie muszą jednak przesądzać o sposobie kreowania potocznych dyskursów, choć odciskają się na przekazie skierowanym do szerszych kategorii społecznych.

\section{PRAKTYCZNY WYMIAR DYSKURSU NARODOWEGO}

Analiza napięć zawartych w obrazie narodu ukraińskiego w dyskursie politycznym i akademickim pozwala z nowej perspektywy przyjrzeć się doświadczeniom $z$ badań terenowych prowadzonych $w$ okresie pewnej stabilizacji społecznej w Ukrainie ${ }^{9}$. Oczywiście badania konkretnych społeczności lokalnych zasadniczo pozwalają wyodrębnić Bachtinowskie siły decentralizujące dyskurs, gdyż w jego koncepcji środowiska społeczne cechuje różnojęzyczność (Bachtin 1982, s. 95). Jednak tak jak w centralizującym języku nauki poszukiwane były rozbieżności, tak w doświadczeniach terenowych chciałbym zwrócić uwagę na takie elementy, które mogą „sklejać” obraz świadomości narodowej w Ukrainie, być może dając ciekawą glosę do teorii narodu. Dwa potencjalne elementy postrzegania narodu, które można wywieść z badań, to budowanie jednej wizji narodu kulturowego na bardzo niespójnych treściach etnicznych oraz tworzenie lokalnie spójnych konglomeratów wyobrażeń etniczno-obywatelskich.

\footnotetext{
9 Odwołuję się tutaj do badań realizowanych w latach 2009-2011 w Drohobyczu i Lwowie w ramach projektu MNiSW N N116 230436 „Antagonizm i pojednanie w środowiskach wielokulturowych" (kierownik prof. dr hab. Jacek Kurczewski [Uniwersytet Warszawski]; główni wykonawcy: prof. dr hab. Halina Rusek [Uniwersytet Śląski], dr Dariusz Wojakowski [Uniwersytet Rzeszowski], prof. Vladislav Volkovs [University of Davgapils, Łotwa]) oraz do badań prowadzonych w ramach kierowanych przeze mnie prac: doktorskiej nt. Zaporoża (Karnaukh 2015) i magisterskiej nt. Mariupola (Rumiantseva 2014).
} 
Pierwsze $z$ tych zjawisk można zaobserwować na Zachodzie Ukrainy. Dobrą jego ilustrację można znaleźć w muzeum regionalnym w Równem na Wołyniu (2009 rok) ${ }^{10}$. Cechą takich muzeów, nie tylko w Ukrainie, jest próba kompleksowego pokazania geograficznej, przyrodniczej, historycznej i kulturowej (etnograficznej) specyfiki regionu. O unikalności tego muzeum stanowi jednak przedstawienie okresu drugiej wojny światowej. Ekspozycja zajmuje dwie sale. Mniejsza z nich poświęcona jest Ukraińskiej Powstańczej Armii (zarówno oddziałom Tarasa Bulby-Borowcia, jak i OUN). Prezentowane są zdjęcia, mundury, dokumenty i broń oraz opisana walka wyzwoleńcza z Niemcami na obszarze dzisiejszego obwodu rówieńskiego. Nie ma natomiast żadnych informacji o walkach z Polakami i Armią Czerwoną. Większa sala poświęcona jest partyzantce komunistycznej i Armii Czerwonej, dokładnie zaś udziałowi mieszkańców obwodu w tych organizacjach militarnych oraz wyzwoleniu obwodu spod okupacji niemieckiej. Dwie różne narracje ukraińskie o drugiej wojnie światowej splatają się w całość, która być może szokuje historyków, ale poprzez znany w socjologii mechanizm tworzy kulturowy projekt narodowy. Oczywiście, jest to ilustracja wyjątkowa i takich zestawów muzealnych nie należy spodziewać się we Lwowie czy Charkowie. Jednak nie tylko w Równem, lecz także w Drohobyczu udało się zaobserwować płynne przenikanie się innych cech kulturowych. Przede wszystkim jest to obecność języka rosyjskiego w przestrzeni publicznej, mimo wyraźnej dominacji w niej języka ukraińskiego. Po drugie, to powszechność kultury popularnej w języku rosyjskim (m.in. piosenek). Są to elementy rozpoznawane przez badaczy jako istotny problem w skali ogólnokrajowej (np. Riabczuk 2004, s. 84-86). Nie jest to jednak problem lokalnych środowisk, które stosują różne konfiguracje kulturowe, także $z$ wieloma elementami z czasów radzieckich (Święto Kobiet, 1 Maja) - są one wewnętrznie „różnojęzyczne” w szerokim, kulturowym rozumieniu. Dość zauważyć, że na społeczność drohobycką składają się nie tylko różne grupy etniczne (Ukraińcy, Rosjanie, Polacy i Żydzi), lecz przede wszystkim trzy kategorie mieszkańców: rodowici drohobyczanie, których rodziny mieszkały tu przed drugą wojną światową, osoby pochodzące $z$ okolicznych wsi oraz dzieci i wnukowie tych, którzy przyjechali tu ze wszystkich regionów Ukrainy. Można zatem przyjąć hipotezę, że u wielu z nich połączenie narracji narodowej w stylu muzeum rówieńskiego nie budziłoby większych kontrowersji. Kultura codzienna i historia narodowa Ukrainy są zatem prawdopodobnie bardzo plastyczne. Ta cecha nawiązuje do pewnych tez zachodniej socjologii narodu, na przykład do koncepcji Jacka Ellera (1999, s. 41-42) — przeszłości jako zasobu, który może służyć zarówno do walki, jak i komunikacji.

Drugie zjawisko obserwowane $\mathrm{w}$ badaniach, które pozwala na przejście od złożoności do jedności jest widoczne zwłaszcza w przypadku mniejszości

10 Moje doświadczenia z Równego wiążą się ze współpracą z Rówieńskim Instytutem Słowianoznawstwa w latach 2006-2012. 
narodowych zamieszkujących południe Ukrainy: Bułgarów (Karanukh 2015) i Greków (Rumiantseva 2014). Ilustracją „etnicznego” sposobu bycia takich grup jest opisany przez Karnaukh festiwal „My - Ukraińscy”:

„Od 1998 roku tradycyjnym świętem regionu stał się międzynarodowy festiwal "My - Ukraińscy», reprezentujący kulturę grup etnicznych zamieszkujących tereny Zaporoża. Festiwal ma duże znaczenie symboliczne: uczestnicy, jak sama nazwa wskazuje, podkreślają, że są Ukraińcami i częścią kultury ukraińskiej niezależnie od pochodzenia etnicznego i pielęgnowania kultury etnicznej. Niemal każda mniejsza lub większa miejscowość Zaporoża bierze udział w organizacji uroczystości. Zespoły taneczne oraz kolektywy muzyczne w ciągu kilku dni odwiedzają miejscowości obwodu, na zasadzie wymiany kulturowej, prezentując własne umiejętności oraz elementy kultur" (Karnaukh 2015, s. 142).

Autorka wskazuje, że intencją takiego projektu jest zestawienie ukraińskości jako kategorii państwowo-obywatelskiej z przynależnością do grupy mniejszościowej rozumianej w kategoriach etnicznych. Istotne jest jednak to, że w większości przypadków jest to „etniczność kulinarna”, sprowadzająca się do odświętnie zachowywanych tradycji ludowych. Pokazują to dokładniejsze badania mniejszości bułgarskiej przeprowadzone przez Allę Karnaukh (2015, s. 181 i nast.). Streszczając wyniki tych analiz można zauważyć, że bułgarskość najczęściej jest tym elementem identyfikacji, który zachowuje się przez wspomnienie tradycji rodzinnych. Istotnym elementem identyfikacji jest język rosyjski (Karnaukh 2015, s. 196, 200), pojawia się też tożsamość lokalna (Karnaukh 2015, s. 192-193). Ukraińskość jest także obecnym w tożsamości tej mniejszości elementem, o wyraźnie państwowej (zamieszkanie w danym kraju) i słabej obywatelskiej konotacji (Karnaukh 2015, s. 198-199).

Dokładnie takie same elementy można było zaobserwować $\mathrm{w}$ świadomości zamieszkujących Mariupol Greków. Co prawda, mają oni wyraźniejsze poczucie odrębności od otoczenia (Rumiantseva 2014, s. 65-66), co wiąże się z pamięcią bardzo skomplikowanej historii tej grupy, uciekającej w XIX wieku spod panowania muzułmańskiego do Rosji (Rumiantseva 2014, s. 37-41). Jednocześnie jest to poczucie raczej regionalnej odrębności (tzw. rumiejskiej), która niekoniecznie przekłada się na poczucie związku z dzisiejszą Grecją ${ }^{11}$. Kultura Greków mariupolskich jest kulturą ludową, mocno zakorzenioną w języku rosyjskim i silniej niż w przypadku Bułgarów wspierającą się na związku z regionem.

Rumiantseva podobnie, jak Karnaukh w odniesieniu do Berdiańska, ocenia relacje etniczne w Mariupolu:

„W mieście nawet wznieśli «Kamień Przyjaźni», który symbolizuje jedność i szacunek dla wszystkich mniejszości miasta. Dlatego jeśli mówimy o konkretnej

11 Jak pisze Rumiantseva (2014, s. 78): „Respondenci mówią o przywiązaniu do Ukrainy, że zawsze ciągnie tam, gdzie są ich korzenie. Grecja nadal jest obca dla Greków z Mariupola, ponieważ ich mentalność i mentalność współczesnej Grecji różni się diametralnie”. 
większości (Ukraińcach), to Grecy uważają ich za braci i krewnych, ponieważ występuje przenikanie tych kultur. [...] W momencie przeprowadzenia badania [2013 rok - D.W.] Grecy prezentowali absolutnie lojalny i pozytywny stosunek do narodu ukraińskiego. [...] Przedstawiciele tej kultury podkreślali również ciepły i życzliwy stosunek Ukraińców do Greków" (Rumiantseva 2014, s. 76).

Rozpoznanie tych układów ma wyłącznie lokalny charakter, a weryfikacja hipotezy, że był to dość powszechny sposób postrzegania problemu narodu na wschodzie Ukrainy, będzie trudna. Dostrzeżone w przywołanych badaniach zjawiska pozwalają jednak twierdzić, że niektóre społeczności zamieszkujące południe Ukrainy przed rokiem 2014 wytwarzały pewną konstrukcję narodu pod wieloma względami podobną do wersji amerykańskiej, w której naród jest kategorią polityczną abstrahującą od różnic etnicznych czy języka komunikacji. Nie można nie zauważyć, że czasy radzieckie wprowadziły taki niezależny od etniczności czynnik państwowy, który potem przejęło i wypełniało (raczej gorzej niż lepiej) państwo ukraińskie. O ile przykłady z zachodniej Ukrainy pokazują plastyczność ukraińskich treści kulturowych, to przykłady ze wschodu odsłaniają inny ich wymiar. Ukraińskość jest w tych przypadkach ogólną ramą etnicznego zróżnicowania nie tylko w granicach państwa, ale wewnątrz regionów i społeczności lokalnych.

Śledząc „osobliwości” przejawów ukraińskiej koncepcji narodu można dostrzec wiele jej nieciągłości, które przekładają się na przywołane w tytule „powszechne niezrozumienie". Celem moim nie było skierowanie uwagi na te aspekty, które pojawiły się $\mathrm{w}$ analizie, lecz od dawna były rozpoznawane: różnice językowe, religijne, podziały regionalne czy ogólnie ulokowanie Ukrainy między Wschodem a Zachodem. Intrygującym elementem ukraińskiego myślenia o narodzie jest prawdopodobna powierzchowność wyobrażeń i symboliki narodowej - wskazany przeze mnie banalny nacjonalizm w warunkach konfliktu międzynarodowego. W warunkach niespójności dyskursów narodowych w tym kraju być może ta powierzchowność, ale i ucodziennienie pewnego zestawu wyobrażeń, jest sposobem zbudowania „części wspólnej” dla wszystkich obywateli Ukrainy. Ze względu na dużą dynamikę przemian społecznych i świadomościowych w dzisiejszej Ukrainie formułowanie wniosków na przyszłość byłoby jednak mało odpowiedzialne.

Dlatego wydaje się, że na koniec można najwyżej podkreślić, iż istotnymi czynnikami niezrozumienia tego, czym jest naród ukraiński, są różnice wyraźnie rozpoznawane na poziomie różnych ukraińskich dyskursów publicznych (polityki, nauki), które nie zawierają treści spajających wyobraźnię społeczną. Należy też wskazać na zjawiska, które mogłyby stanowić treść sił centralizujących: powierzchowny, lecz obywatelski model kultury państwowej oraz dwujęzyczność. Niestety te składowe świadomości narodowej ujawniają się 
lokalnie i nie są w stanie przebić się na poziom dyskursów ogólnopaństwowych.

Szczególnym problemem jest zaś to, że w sposób naturalny socjologia ukraińska posługuje się zachodnioeuropejskimi teoriami narodu, lecz w miarę kompletny model relacji międzyetnicznych $\mathrm{w}$ państwie wielonarodowym pojawia się na południu kraju i pasuje raczej do rozwiązań znanych z państw amerykańskich (np. z Kanady). W warunkach konfliktu z sąsiadem przywiązanym do prymodrialnej koncepcji narodu (promowana przez Rosję idea euroazjatyzmu) te wypracowane wcześniej „multietniczne” modele relacji wydają się raczej nie do utrzymania, choć były to - w moim przekonaniu - lokalnie dobrze działające schematy przekształcania społeczeństwa postradzieckiego w kierunku jakiejś wersji społeczeństwa obywatelskiego.

\section{BIBLIOGRAFIA}

Anderson Benedict, 1997, Wspólnoty wyobrażone, tłum. Stefan Amsterdamski, Znak, Kraków.

Babiński Grzegorz, 1997, Pogranicze polsko-ukrainskie. Etniczność, zróżnicowanie religijne, tożsamość, Nomos, Kraków.

Bachtin Michaił, 1982, Stowo w powieści, w: Michaił Bachtin, Problemy literatury i estetyki, tłum. Wincenty Grajewski, Czytelnik, Warszawa.

Berger Peter L., Luckmann Thomas, 1983, Społeczne tworzenie rzeczywistości, tłum. Józef Niżnik, Państwowy Instytut Wydawniczy, Warszawa.

Billig Michael, 2008, Banalny nacjonalizm, tłum. Maciek Sekerdej, Znak, Kraków.

Briggs Charles, 2001, Anthropology of Discourse, w: Neil J. Smelser, Paul B. Baltes (red.), International Encyclopedia of the Social and Behavior Sciences, Elsevier Science Lmt., Palo Alto-Berlin.

Budyta-Budzyńska Małgorzata, 2010, Socjologia narodu i konfliktów etnicznych, Wydawnictwo Naukowe PWN, Warszawa.

Clifford James, 2000, Kłopoty z kultura. Dwudziestowieczna etnografia, literatura $i$ sztuka, tłum. Ewa Dżurak i in., Wydawnictwo KR, Warszawa.

Crapanzano Victor, 1999, Kryzys postmodernistyczny: dyskurs, parodia, pamięć, w: Michał Buchowski (red.), Amerykańska antropologia postmodernistyczna, Instytut Kultury, Warszawa.

Czernysz Natalija, 2002, Odna, dwi czy dwadcat' dwi Ukrajiny. Sociotohicznyj analiz socialnych identycznostej predstawnykiw trioch pokoteń meszkanciw Lwowa i Donećka, „Duch i litera”, nr 11-12.

Dugin Aleksandr, 2004, Projekt „Jewrazija”, Jauza, Moskwa.

Dugin Aleksandr, 2011, Etnosociotogija, Akadiemiczeskij Projekt, Moskwa.

Edensor Tim, 2004, Tożsamość narodowa, kultura popularna i życie codzienne, tłum. Agata Sadza, Wydawnictwo UJ, Kraków.

Eller Jack, 1999, From Culture to Ethnicity to Conflict, University of Michigan Press, Michigan.

Fairclough Norman, Duszak Anna, 2008, Wstęp: Krytyczna analiza dyskursu — nowy obszar badawczy dla lingwistyki i nauk społecznych, w: Norman Fairclough, Anna Duszak (red.), Krytyczna analiza dyskursu. Interdyscyplinarne podejście do komunikacji społecznej, Universitas, Kraków.

Gdula Piotr, 2014, Studenci przemyskiej uczelni z banderowska flaga - nasza opinia, „Portal Przemyski.pl”, 17 października (http://www.portalprzemyski.pl/studenci_przemyskiej_uczelni_z_ banderowska_flaga).

Geertz Clifford, 2005, Interpretacja kultur. Wybrane eseje, tłum. Maria M. Piechaczek, Wydawnictwo UJ, Kraków. 
Gellner Ernest, 1991, Narody i nacjonalizm, tłum. Teresa Hołówka, Państwowy Instytut Wydawniczy, Warszawa.

Giddens Anthony, 2001, Nowoczesność $i$ tożsamość. „Ja” i spoteczeństwo w epoce późnej nowoczesności, tłum. Alina Sulżycka, Wydawnictwo Naukowe PWN, Warszawa.

Gorczyca Anna, 2014, Studenci sfotografowali się z flagą UPA. Teraz zajmie się nimi prokurator, „Wyborcza.pl", 21 października (http://rzeszow.gazeta.pl/rzeszow/1,34962,16843097,Studenci sfotografowali_sie_z_flaga_UPA_Teraz_zajmie.html).

Hroch Miroslav, 2003, Mate narody Europy. Perspektywa historyczna, tłum. Grażyna Pańko, Ossolineum, Wrocław.

Hrycak Jarosław, 2000, Historia Ukrainy 1772-1999. Narodziny nowoczesnego narodu, tłum. Katarzyna Kotyńska, Instytut Europy Środkowo-Wschodniej, Lublin.

Hrycak Jarosław, 2002, Pro sensownist' i bezsensownist' nacionalizmu w Ukrajini, „Duch i litera”, nr 11-12 .

Huntington Samuel, 1997, Zderzenie cywilizacji i nowy kształt ładu światowego, tłum. Hanna Jankowska, Muza, Warszawa.

Jestal Jerzy, 1999, Polsko-ukraińskie dyskusje w kontekście stereotypów narodowościowych, w: Marian Malikowski, Dariusz Wojakowski (red.), Między Polska a Ukrainą. Pogranicze - mniejszości wspótpraca regionalna, Mana, Rzeszów.

Karnaukh Alla, 2008, Rosyjskojęzyczni Ukraincy - mniejszość we wtasnym państwie, w: Janusz Mucha, Bożena Pactwa (red.), „Status mniejszościowy” i ambiwalencja tożsamości $w$ spoteczeństwach wielokulturowych, Śląskie Wydawnictwo Naukowe, Tychy.

Karnaukh Alla, 2009, Prawny status jezzyków na Ukrainie a rzeczywisty jego stan, w: „Fenomen pogranicz kulturowych: współczesne tendencje”, tom 2, Państwowa Wyższa Szkoła Zawodowa im. Stanisława Staszica, Piła-Berdiańsk.

Karnaukh Alla, 2015, Pomiędzy ukraińskością a sowieckością. Ukraińcy, Rosjanie i Bułgarzy na Zaporożu, Nomos, Kraków.

Kasjanow Heorhij, 1999, Teoriji naciji i nacionalizmu, Łybid', Kyjiw.

Kiś Roman, 2005, Htobalne, nacionalne, lokalne, Litopys, Lwiw.

Kłoskowska Antonina, 1996, Kultury narodowe u korzeni, Wydawnictwo Naukowe PWN, Warszawa.

Kurczewski Jacek, 2010, Ślady Schulzowskiego Drohobycza w Drohobyczu dzisiejszym - spojrzenie socjologa, w: Wiera Meniok (red.), Inspiracje Schulzowskie w literaturze, Polonistyczne Centrum Naukowo-Informacyjne im. I. Menioka, Drohobycz.

Kurczewski Jacek, Wojakowski Dariusz, 2012, O Drohobyczu, odkrywanej wielokulturowości i niewypowiedzianym pojednaniu, w: Jacek Kurczewski, Aleksandra Herman (red.), Antagonizm i pojednanie $w$ środowiskach wielokulturowych, słowo/obraz terytoria, Gdańsk.

Kuzio Taras, 2002, Nationalism in Ukraine: Towards a New Theoretical and Comparative Framework, „Journal of Political Ideologies”, t. 7, nr 2, s. 133-161.

Panina Nataliia, 2004, O zastosowaniu skali dystansu spolecznego $w$ badaniach tolerancji na Ukrainie, „Studia Socjologiczne”, nr 4.

Pawluczuk Włodzimierz, 1998, Ukraina. Polityka i mistyka, Nomos, Kraków.

Picza Wołodymyr, 2002, Sociołohija. Terminy - poniattia — personaliji, Karaweła, Kyjiw.

Riabczuk Mykoła, 2004, Dwie Ukrainy, tłum. zbiorowe, Kolegium Europy Wschodniej, Wrocław.

Rumiantseva Anna, 2014, „Grecka mniejszość narodowa w Mariupolu”, Wydział Humanistyczny AGH (praca magisterska).

Suchecka Justyna, 2014, Ukraińscy studenci z Przemyśla fotografowali się z flaga UPA. Internauci atakuja ich uczelnię, „Wyborcza.pl”, 17 października (http://wyborcza.pl/1,75478,16821228,Ukrainscy _studenci_z_Przemysla_fotografowali_sie_z.html).

Suprunenko Olha, 2008, Sensy społeczne versus struktura społeczeństwa ukraińskiego: szkic hipotetyczny, tłum. Bogdan Salej, „Nowa Ukraina”, z. 1-2. 
Szacki Jerzy, 2002, Historia myśli socjologicznej. Wydanie nowe, Wydawnictwo Naukowe PWN, Warszawa.

Szymanik Grzegorz, 2014, Zła flaga, „Wyborcza.pl”, 6 listopada (http://wyborcza.pl/duzyformat/ 1,141504,16916487,Zla_flaga.html).

Tychomyrowa Jewhenija, 2007, Osnowy sociołohiji, Perspektywa, Riwne.

Wojakowski Dariusz, 2002, Polacy i Ukraińcy. Rzecz o pluralizmie i tożsamości na pograniczu, Nomos, Kraków.

Wojakowski Dariusz, 2007, Swojskość i obcość w zmieniającej się Polsce, Wydawnictwo IFiS PAN, Warszawa.

Wojakowski Dariusz, 2010, Die gegenwärtige Ethnizität im wissenschaftlichen Diskurs und in den individuellen Selbst- und Fremdeninterpretationen, w: Anna Duszak, Juliane House, Łukasz Kumięga (red.), Globalization, Discourse, Media: In a Critical Perspective / Globalisierung, Diskurse, Medien: eine kritische Perspektive, Wydawnictwo Uniwersytetu Warszawskiego, Warszawa.

Wojakowski Dariusz, 2014, Past, Conflict and Seeking of Reconciliation on the Polish-Ukrainian Borderland, w: Jacek Kurczewski (red.), Reconciliation in Bloodlands: Assessing Actions and Outcomes in Contemporary Central-Eastern Europe, Peter Lang Verlag, Frakfurt am Main.

Wojakowski Dariusz, Karnaukh Alla, 2012, Rajd Śladami Bandery w sierpniu 2009 r. jako zjawisko ilustrujące ksztattowanie ram dyskursu polsko-ukraińskiego na pograniczu, w: Jacek Kurczewski (red.), Socjologia pojednania, Nomos, Kraków.

Yekelchyk Serhy, 2009, Ukraina. Narodziny nowoczesnego narodu, tłum. Joanna Gilewicz, Wydawnictwo UJ, Kraków

Oświadczenie studentów PWSW w Przemyślu (http://www.pwsw.pl/aktualnosci/id6625,Oswiad czenie-studentow-PWSW-w-Przemyslu.html).

Strona komisji wyborczej Ukrainy: http://www.cvk.gov.ua/pls/vnd2012/wp315?PT001F01 =900

http://www.cvk.gov.ua/pls/vnd2014/wp300?PT001F01 =910

http://www.cvk.gov.ua/pls/vnd2014/wp315?PT001F01 =910

\section{THE UKRAINIAN NATION AS AN OBJECT OF GENERAL MISUNDERSTANDING}

\section{Summary}

The article contains an analysis of the academic and popular political discourses concerning the Ukrainian nation. Its aim is to point out atypical phenomena which could constitute little-known factors destabilizing or integrating national self-representation in Ukraine. The inconsistency of these concepts occurs above all at the level of macro-social discourses. What is involved is the presence in politics of content associated with the radical right and its primordial understanding of the nation, accompanied by low support for any sort of national or civil idea among the inhabitants of Ukraine. In the academic discourse the dominant western European theories of nation clash with a specific understanding of the terminology used in Russian scholarship. On the other hand, in local discourses at the meso-social level, there are phenomena that could be integrating factors for the image of the Ukrainian nation. There, language, popular culture, and various ideas about the past intermingle. In southern Ukraine, concepts can be found in which the nation is a political category quite aside from ethnic differences or the language of communication. Soviet times introduced the state factor, which is 
independent of ethnicity and which was later given content (rather worse than better) by the Ukrainian state. In these cases, Ukrainianness appears as a superior principle in regards to ethnic differentiation. The political situation of Ukraine since 2014, however, does not favor the development of this model of the Ukrainian nation.

\section{Key words/słowa kluczowe}

Ukraine / Ukraina; theories of nation / teorie narodu; discourse / dyskurs; Ukrainian national consciousness / ukraińska świadomość narodowa 